\title{
1 Gut microbiota predict Enterococcus expansion but not Vancomycin-resistant
}

\section{Enterococcus acquisition}

3 Rishi Chanderraj MD ${ }^{1,2}$, Christopher A. Brown ${ }^{2}$, Kevin Hinkle ${ }^{2}$, Nicole Falkowski²,

4 Piyush Ranjan ${ }^{2}$, Robert P. Dickson ${ }^{2,3, a}$, Robert J. Woods ${ }^{1,4, a}$

5 1. Division of Infectious Diseases, Department of Internal Medicine, University of

6 Michigan Medical School, Ann Arbor, MI, USA.

7 2. Division of Pulmonary and Critical Care Medicine, Department of Internal Medicine,

8 University of Michigan Medical School, Ann Arbor, MI, USA.

9 3. Department of Microbiology and Immunology, University of Michigan Medical School, 10 Ann Arbor, MI, USA.

11 4. Computational Medicine and Bioinformatics, University of Michigan Medical School, 12 Ann Arbor, MI, USA.

13 a. These authors contributed equally to this work.

14 Keywords: Microbiome, Vancomycin-resistant Enterococcus, colonization resistance,

15 hospital-acquired infection

16 Running title: Gut microbiota and VRE infection

17 Summary: $16 \mathrm{~S}$ profile of the gut microbiome does not predict VRE acquisition in

18 hospitalized patients, likely due to the rapid and profound microbiota change in this

19 population. VRE expansion and VRE acquisition may be two distinct processes.

20 Corresponding Author:

21 Robert Woods

22 5520A MSRB III

231150 W. Medical Center Drive

24 Ann Arbor, Ml 48109

25 734-647-5899

26 robertwo@med.umich.edu 
medRxiv preprint doi: https://doi.org/10.1101/2020.05.26.20114181; this version posted May 28, 2020. The copyright holder for this preprint

(which was not certified by peer review) is the author/funder, who has granted medRxiv a license to display the preprint in perpetuity.

It is made available under a CC-BY-NC-ND 4.0 International license .

\section{ABSTRACT}

28 BACKGROUND: Vancomycin-resistant Enterococcus (VRE) is a leading cause

29 of hospital-acquired infections, and continues to spread despite widespread

30 implementation of pathogen-targeted control guidelines. Commensal gut

31 microbiota provide colonization resistance to VRE, but the role of gut microbiota

32 in VRE acquisition in at-risk patients is unknown.

33 METHODS: We performed a case-control study of gut microbiota in hospitalized

34 patients who did (cases) and did not (controls) acquire VRE. We matched case

35 subjects to control subjects by known risk factors and "time at risk," defined as

36 the time elapsed between admission until positive VRE screen. We characterized

37 gut bacterial communities using 16S rRNA gene amplicon sequencing of rectal

38 swab specimens.

39 RESULTS: We analyzed 236 samples from 59 matched case-control pairs. At

40 baseline, case and control subjects did not differ in gut microbiota when

41 measured by community diversity $(p=0.33)$ or composition $(p=0.30)$. After

42 hospitalization, gut communities of cases and controls differed only in the

43 abundance of the Enterococcus containing operational taxonomic unit (OTU),

44 with the gut microbiota of case subjects having more of this OTU than time-

45 matched control subjects $(p=0.01)$. Otherwise, case and control communities

46 after the time at risk did not differ in diversity $(p=.33)$ or community structure

$47(p=0.12)$. Among patients who became VRE colonized, those having the Blautia

48 containing OTU on admission had lower Enterococcus relative abundance once

49 colonized $(p=0.004)$. 
50 CONCLUSIONS: The $16 \mathrm{~S}$ profile of the gut microbiome does not predict VRE

51 acquisition in hospitalized patients, likely due to rapid and profound microbiota

52 change. The gut microbiome does not predict VRE acquisition, but may be

53 associated with Enterococcus expansion, suggesting that these should be

54 considered as two distinct processes.

\section{INTRODUCTION:}

57 Vancomycin-resistant Enterococcus (VRE) is a highly antibiotic-resistant

58 bacteria, is a leading cause of healthcare-associated infections, and is classified

59 as a serious public health threat by the Centers for Disease Prevention and

60 Control[4,5]. Colonization with VRE precedes infection[6,7], and molecular

61 epidemiologic analyses show patient-to-patient hospital transmission is the

62 primary means of spread[8]. Preventing transmission between hospitalized

63 patients is a significant challenge, and despite the widespread application of

64 pathogen-targeted control measures[9], VRE remains endemic in many

65 hospitals[4,5].

67 Both indirect human evidence and animal experimentation demonstrate that gut

68 microbiota prevent VRE colonization when a patient is exposed, a phenomenon

69 termed "colonization resistance" [2,10,11]. Colonization resistance may entail

70 competition for resources, secretion of bactericidal factors[3,12], and indirect

71 stimulation of host immune defense mechanisms that target VRE[13,14]. Though

72 colonization resistance plays a crucial role in suppressing VRE expansion and 
medRxiv preprint doi: https://doi.org/10.1101/2020.05.26.20114181; this version posted May 28, 2020. The copyright holder for this preprint

73 preventing VRE infection[1,15], to date, no study has evaluated whether variation

74 in intestinal microbiota can explain variation in VRE acquisition among at-risk

75 patients.

76 To address this gap in our understanding of VRE transmission, we investigated

77 whether the gut microbiome of at-risk patients predicts VRE colonization in a

78 hospitalized patient population. We hypothesized that if the gut microbiome can

79 confer colonization resistance for VRE acquisition, variation in baseline

80 microbiota would explain variation in patient susceptibility to VRE acquisition. To

81 test this hypothesis, we designed a case-control study using 16S rRNA gene

82 amplicon sequencing of rectal swabs acquired from hospitalized patients.

84 METHODS:

\section{Study setting and design:}

86 We previously conducted a retrospective case-control study of clinical risk factors

87 for VRE acquisition among patients who did (cases) and did not (controls)

88 acquire VRE during their admissions at the University of Michigan Healthcare

89 System from January 2013 until June 2016[16]. We studied gut microbiome

90 communities in 236 rectal swab samples from 59 matched pairs of case and

91 control subjects from patients admitted to the University of Michigan Hospital in

922016.64 out of 118 subjects in this study (54\%) were a part of our previous

93 clinical risk factor analysis. The remaining subjects were admitted from June to

94 December 2016 (outside the timeframe of the previous study by six months). The

95 University of Michigan Healthcare system consists of $\sim 1000$ inpatient beds and 
medRxiv preprint doi: https://doi.org/10.1101/2020.05.26.20114181; this version posted May 28, 2020. The copyright holder for this preprint

(which was not certified by peer review) is the author/funder, who has granted medRxiv a license to display the preprint in perpetuity.

It is made available under a CC-BY-NC-ND 4.0 International license .

96 serves as a tertiary referral hospital for southeastern Michigan. The institutional

97 review board at the University of Michigan approved the study before its initiation.

99 The infection control practice throughout the study period was to perform routine

100 surveillance for VRE on eight adult units, including intensive care units, the

101 hematology and oncology ward, and the bone marrow transplant ward. All

102 patients were routinely screened on admission and weekly thereafter with rectal

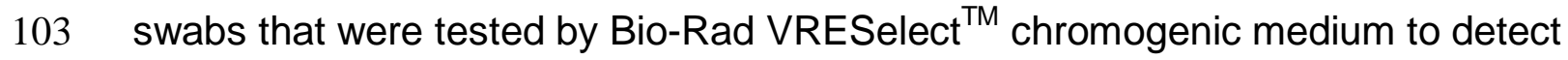

104 VRE. Cases were defined as subjects with an initial negative swab followed by a

105 positive swab when evaluated by this selective culture. We further identified the

106 "time at risk" for each case patient, here defined as the time elapsed between

107 admission and positive VRE screen. We matched each case subject to a control

108 subject with an initial negative swab followed by repeat negative swab within the

109 same time at risk (+/- 5\%). An additional matching factor was the unit from which

110 the first positive VRE was recovered for cases or the matched swab after the

111 time at risk for controls.

112

\section{Bacterial DNA isolation:}

114 Genomic DNA was extracted from rectal swabs re-suspended in $360 \mu \mathrm{l}$ ATL

115 buffer (Qiagen DNeasy Blood \& Tissue kit) and homogenized in fecal DNA bead

116 tubes using a modified protocol previously demonstrated to isolate bacterial

117 DNA[17,18]. Sterile laboratory water and AE buffer used in DNA isolation were

118 collected and analyzed as potential sources of contamination. ZymoBIOMICS 
medRxiv preprint doi: https://doi.org/10.1101/2020.05.26.20114181; this version posted May 28, 2020. The copyright holder for this preprint

(which was not certified by peer review) is the author/funder, who has granted medRxiv a license to display the preprint in perpetuity.

It is made available under a CC-BY-NC-ND 4.0 International license .

119 Microbial Community DNA Standard (Zymo Research cat\# D6306) was

120 sequenced for error analysis.

121 16s rRNA gene sequencing

122 The V4 region of the 16s rRNA gene was amplified using published primers and

123 the dual-indexing sequencing strategy developed previously [17]. Sequencing

124 was performed using the Illumina MiSeq platform (San Diego, CA), using a

125 MiSeq Reagent Kit V2 (500 cycles), according to the manufacturer's instructions

126 with modifications found in the standard operating procedure of the laboratory of

127 Dr. Patick Schloss [17,19]. Accuprime High Fidelity Taq was used in place of

128 Accuprime Pfx SuperMix[20]. Primary PCR cycling conditions were $95^{\circ} \mathrm{C}$ for two

129 minutes, followed by 20 cycles of touchdown PCR $\left(95^{\circ} \mathrm{C} 20\right.$ seconds, $60^{\circ} \mathrm{C} 20$

130 seconds and decreasing 0.3 degrees each cycle, $72^{\circ} \mathrm{C}$ for 5 minutes), then 20

131 cycles of standard $\mathrm{PCR}\left(95^{\circ} \mathrm{C}\right.$ for 20 seconds, $55^{\circ} \mathrm{C}$ for 15 seconds, and $72^{\circ} \mathrm{C}$ for

1325 minutes), and finished with $72^{\circ} \mathrm{C}$ for 10 minutes.

\section{Statistical analyses:}

135 Sequence data were processed and analyzed using the software mothur

136 v.1.43.0[21] according to the standard operating procedure for MiSeq sequence

137 data using a minimum sequence length of 250 base pairs $[17,22]$. To summarize,

138 the SILVA rRNA database[23] was used as a reference for sequence alignment

139 and taxonomic classification. K-mer searching with 8mers was used to assign

140 raw sequences to their closest matching template in the reference database, and

141 pairwise alignment was performed with the Needleman-Wunsch[24] and NAST 
medRxiv preprint doi: https://doi.org/10.1101/2020.05.26.20114181; this version posted May 28, 2020. The copyright holder for this preprint

(which was not certified by peer review) is the author/funder, who has granted medRxiv a license to display the preprint in perpetuity.

It is made available under a CC-BY-NC-ND 4.0 International license .

142 algorithms[25]. A k-mer based Naïve Bayesian classifier[26] was used to assign

143 sequences to their correct taxonomy with a bootstrap confidence score threshold

144 of 80 . Pairwise distances between aligned sequences were calculated with the

145 method employed by Sogin et al. [27], where pairwise distance equals

146 mismatches, including indels, divided by sequence length. A distance matrix was

147 passed to the OptiCLUST clustering algorithm[28] to cluster sequences into

148 'Operational Taxonomic Units' (OTUs) by maximizing the Matthews Correlation

149 Coefficient with a dissimilarity threshold of 3\%[29].

150

151 After clustering and classification of raw sequencing data, we evaluated

152 differences in community structure with Permutational multivariate analysis of

153 variance (PERMANOVA) in the vegan package $(v 2.0-4)[30]$ in $R(v$ 3.6.4) [31].

154 We performed resampling of multiple generalized linear models with the

155 mvabund[32] package in $\mathrm{R}$ to look for individual OTU differences between

156 communities. We set a significance threshold of 0.01 after adjusting for multiple

157 comparisons using a stepdown resampling procedure to reduce the type I error

158 rate[33]. We confirmed individual OTU differences with random forest

159 classification and regression models built with the ranger package in $R(v 0.11 .2)$

160 [34]. We used the caret ( $v$ 6.0-84)[35] package in $\mathrm{R}$ for cross-validation and to

161 optimize the hyperparameters of the number of decision trees in the model and

162 the number of features considered by each tree when splitting a node. We

163 corrected for feature importance bias in random forest models with a permutation

164 importance (PIMP) heuristic developed by Altmann et al. [36]. All OTUs were 
medRxiv preprint doi: https://doi.org/10.1101/2020.05.26.20114181; this version posted May 28, 2020. The copyright holder for this preprint

165 included in diversity and abundance analyses. We performed bivariate analysis

166 with conditional logistic regression using the survival (v 3.1-8) package in

$167 \mathrm{R}[37,38]$. Differences in means of final Enterococcus abundance in cases only

168 were compared with the non-parametric Mann-Whitney U-Test. We used the

169 vegan package in $\mathrm{R}$ to calculate both the average species diversity in an

170 individual rectal swab (Shannon Diversity) and the change in community

171 structure between initial swab and second swab for each subject (Jaccard

172 Distance). We used Spearman's rank correlation coefficient to determine if

173 Jaccard distance was significantly correlated with the time between swabs, and

174 used non-linear least squares regression to fit a model of Jaccard Distance over

175 time for cases and controls.

\section{Adequacy of Sequencing}

178 We performed 16S rRNA gene amplicon sequencing on 236 rectal swab

179 specimens and 15 negative control specimens, which identified 1,188 unique

180 operational taxonomic units (OTUs, genus-level bacterial taxa) at a dissimilarity

181 threshold of $3 \%$. After bioinformatics processing, the mean number of reads per

182 sample was $71,484 \pm 2,684$. No specimens were excluded from the analysis.

183 Rectal swab specimens had clear differences in community structure compared

184 to control specimens, which was confirmed as statistically significant using

185 multiple methods of hypothesis testing [mvabund and PERMANOVA (adonis),

$186 \mathrm{p} \square<\square 0.01$ both] (Supplemental figure 1). Sequences generated from negative

187 control specimens were dominated by a single Pseudomonas-classified OTU 
medRxiv preprint doi: https://doi.org/10.1101/2020.05.26.20114181; this version posted May 28, 2020. The copyright holder for this preprint (which was not certified by peer review) is the author/funder, who has granted medRxiv a license to display the preprint in perpetuity.

It is made available under a CC-BY-NC-ND 4.0 International license .

188 (OTU001). This OTU was included in all reported analyses, though the exclusion

189 of this OTU did not affect any of the reported results.

191 Data availability

192 Sequences are available via the NCBI Sequence Read Archive (accession

193 number PRJNA633879). OTU tables, taxonomy classification tables, and

194 metadata tables are available at

195 https://github.com/rishichanderraj/Microbiota Predictors VRE Acquisition.

197 RESULTS:

198 Study population and medication exposures

199 We studied gut microbiome communities in 236 rectal swab samples from 59

200 matched pairs of case and control subjects (Table 1). Cases and controls did not

201 differ in demographics (age, sex, ethnicity) nor in the relative frequency of

202 common comorbidities (e.g. immunosuppression, malignancy, or gastrointestinal

203 disease). Antibiotic use was widespread among all subjects and was nearly

204 equal across groups (Table 2). Vancomycin, cefepime, metronidazole, and

205 piperacillin-tazobactam were the most commonly used antibiotics in the study

206 population. Cases and controls did not differ significantly in their exposure to any

207 specific antibiotics prior to initial sampling. More cases received proton pump

208 inhibitors prior to initial sampling $(P=0.04)$. During time-at-risk (between initial

209 and subsequent sampling), case and controls did not differ in their exposure to

210 antibiotics or proton pump inhibitors. 
medRxiv preprint doi: https://doi.org/10.1101/2020.05.26.20114181; this version posted May 28, 2020. The copyright holder for this preprint (which was not certified by peer review) is the author/funder, who has granted medRxiv a license to display the preprint in perpetuity.

It is made available under a CC-BY-NC-ND 4.0 International license .

\section{Admission gut microbiota do not predict VRE acquisition.}

212 We first compared baseline microbiota across patients who did (cases) and did

213 not (controls) subsequently acquire VRE. Baseline gut communities of cases and

214 controls did not differ in their community composition, determined either via

215 permutation testing $(\mathrm{p}=0.30$ by PERMANOVA) or via visualization (principal

216 component analysis, Figure 1a). Similarly, baseline gut communities of cases

217 and controls did not differ in their species diversity as measured by the Shannon

218 diversity index (mean of $2.72 \pm 0.90$ for controls, mean of $2.71 \pm 0.76$ for cases,

$219 \mathrm{p}=0.96$ for all matched case-control pairs) (Figure 1b). We concluded that the

220 gut microbiota, as represented by the $16 \mathrm{~S}$ profile of these samples of

221 hospitalized patients, do not predict subsequent VRE acquisition.

223 At the time of VRE detection, the gut communities of cases and controls

224 differ only in the abundance of Enterococcus

225 We next compared gut communities across matched cases and controls after

226 time-at-risk: after cases had been colonized and time-matched controls had not.

227 After time-at-risk, gut microbiota did differ across cases and controls $(p<0.001$,

228 by PERMANOVA), though Shannon diversity index did not (mean of $2.38 \pm 0.106$

229 for controls, mean of $2.22 \pm 0.115$ for cases, $p=0.33$ for all matched case-control

230 pairs). The difference in gut microbiota was driven by the increased relative

231 abundance of a single OTU, the Enterococcus-classified taxonomic group

232 (OTU0004), which was greater in cases than controls $[\mathrm{p}=0.01$ via mvabund,

$233 \mathrm{p}<0.001$ via Random Forest] (Figure 2). When this Enterococcus OTU was 
medRxiv preprint doi: https://doi.org/10.1101/2020.05.26.20114181; this version posted May 28, 2020. The copyright holder for this preprint

234 excluded from the analysis, we found no significant difference in communities

235 across cases and controls [ $\mathrm{p}=0.12$ by PERMANOVA] (Figure 3 ). We thus

236 concluded that at the time of VRE acquisition, the gut microbiota of VRE-infected

237 and uninfected patients differ only in the relative abundance of Enterococcus,

238 and do not consistently differ in their non-Enterococcus microbiota.

240 Gut microbiota change rapidly and profoundly in hospitalized patients

241 Given the lack of differentiation of gut communities across cases and controls at

242 admission and at the time of VRE colonization, we then asked if the temporal

243 change in gut microbiota could distinguish the two groups. We did this by

244 calculating the relative dissimilarity of admission and index (time-at-risk)

245 communities for each subject using Jaccard Distance, a metric of dissimilarity

246 between gut microbial communities measured on a scale of 0 (complete

247 similarity) to 1 (complete dissimilarity, Figure 4). The gut communities of both

248 groups underwent a rapid, profound change in composition. Within several days

249 of admission, gut communities of both cases and controls bore little similarity to

250 the communities detected at the time of admission. Size of change in gut

251 communities did not differ across cohorts $(0.87 \pm 0.016$ for cases, $0.86 \pm 0.017$

252 controls, $\mathrm{p}=0.84)$. Cases and controls also had similar decreases in Shannon

253 diversity $(-0.48 \pm 0.090$ for cases, $-0.40 \pm 0.077$ for controls, $p=0.93$ for all

254 matched case-control pairs). We found that Jaccard distance was significantly

255 correlated with time (Spearman's rank correlation coefficient $\rho=0.32, p=0.0006$ ),

256 and determined that a negative exponential model best fit the data, with gut 
medRxiv preprint doi: https://doi.org/10.1101/2020.05.26.20114181; this version posted May 28, 2020. The copyright holder for this preprint

257 microbiota approaching complete dissimilarity at an exponential rate of $0.47 *$

$258 e^{-0.47 * t+32}$ ( $t$ representing the time between swabs). We found no significant

259 difference in the rate of change between the two groups. We noted that the

260 predicted mean Jaccard distance for two rectal swab samples taken on the same

261 day $(\mathrm{t}=0)$ was $0.79 \pm 0.058$, implying a substantial amount of variation in

262 community structure within the same day of admission.

264 Gut microbiota on admission are associated with Enterococcus expansion

265 Finding no difference in the community composition, diversity, or temporal rate of

266 change across patients who did (cases) and did not (controls) acquire VRE

267 during their hospitalization, we asked if gut microbiota on admission could predict

268 the relative abundance of Enterococcus in VRE colonized patients. We restricted

269 our analysis to case subjects and built a random forest regression model to

270 identify taxa present on admission that were predictive of final Enteroccus

271 relative abundance. Only Blautia and Lactobacillus were significant after

272 correcting for multiple testing and feature importance bias (Figure 5,

273 Supplemental Table 1, Supplemental Figure 2). Blautia spp (OTU 0092) on

274 admission was predictive of decreased Enterococcus $(-10.3 \%$ relative

275 abundance adjusted $p=0.004$ by Mann-Whitney U-test), and Lactobacillus spp

276 (OTU 0026) was with an increased abundance of Enterococcus after the time at

277 risk $(+12.5 \%$ relative abundance $p=0.007$ by Mann-Whitney $U-T e s t)$. Thus, we

278 found that the presence of specific anaerobes previously implicated in

279 Enterococcus colonization resistance[2,15,40] are predictive of decreased 
medRxiv preprint doi: https://doi.org/10.1101/2020.05.26.20114181; this version posted May 28, 2020. The copyright holder for this preprint (which was not certified by peer review) is the author/funder, who has granted medRxiv a license to display the preprint in perpetuity.

It is made available under a CC-BY-NC-ND 4.0 International license .

280 Enterococcus abundance in VRE colonized patients. These findings suggest that

281 VRE acquisition and Enterococcus expansion are two distinct processes with

282 different risk factors and pathophysiology.

283

284 DISCUSSION:

285 In this study gut microbiota did not predict VRE acquisition in hospitalized

286 patients. Secondary analysis identified individual members of the gut microbiota

287 that do predict Enterococcus abundance at the time of VRE acquisition, implying

288 that acquisition and expansion of VRE may be distinct processes. The

289 community composition, diversity, and temporal rate of change did not differ

290 across patients who did (cases) and did not (controls) acquire VRE during their

291 hospitalization. As expected based on the study design, gut communities of

292 cases had a greater abundance of Enterococcus than controls after the time at

293 risk.

294

295 Gut communities of all subjects demonstrated a rapid and dramatic change

296 during hospitalization that was time-dependent. In this population, antibiotic use

297 was prevalent (Table 2), gut microbial communities were remarkably dynamic

298 (Figure 5), and admission gut microbiota provided very little information about

299 microbiota after the time at risk. Our model of Jaccard distance over time

300 estimated a mean Jaccard distance of 0.79 between two rectal swabs taken on

301 the same day of admission, implying that only $21 \%$ of gut microbiota remain

302 constant with resampling within 24 hours. Given the significant correlation 
medRxiv preprint doi: https://doi.org/10.1101/2020.05.26.20114181; this version posted May 28, 2020. The copyright holder for this preprint

303 between Jaccard distance and time, some of this change is likely due to the

304 disruptive pressures that face gut microbiota upon hospitalization (i.e.,

305 antibiotics). However, a large portion of this change may represent stochasticity

306 and noise introduced by variation in sample collection and storage. These results

307 have important implications for the clinical use of gut microbiota for therapy,

308 prediction, and risk stratification. Given the rapid change of gut communities

309 upon hospitalization, a single static $16 \mathrm{~S}$ analysis of gut microbiota may miss

310 subtle dynamics important for VRE acquisition and is subject to a large amount of

311 noise that may obscure a true biologically meaningful association. Future study of

312 the gut microbiota in VRE acquisition may need to move beyond traditional $16 \mathrm{~S}$

313 analysis, which can be time-consuming and miss important species-level

314 information [41,42]. Real-time metagenomics and rapid, ultrasensitive

315 quantification technologies hold promise as tools with better resolution to

316 evaluate these processes [43,44].

318 Despite the dramatic change in community structure, we did find some evidence

319 of colonization resistance, as admission microbiota were predictive of

320 Enterococcus abundance at the time of VRE detection. VRE colonized subjects

321 with Blautia had less Enterococcus expansion, consistent with prior studies

$322[2,15,40]$. We hypothesize that there may be a distinction between VRE

323 acquisition and VRE expansion. In conjunction with earlier studies $[2,40,45]$, our

324 findings suggest that commensal anaerobes may play a significant role in

325 suppressing VRE once colonized. In this context, our results further support the 
medRxiv preprint doi: https://doi.org/10.1101/2020.05.26.20114181; this version posted May 28, 2020. The copyright holder for this preprint

(which was not certified by peer review) is the author/funder, who has granted medRxiv a license to display the preprint in perpetuity.

It is made available under a CC-BY-NC-ND 4.0 International license .

326 possibility of microbiome manipulation to reduce VRE burden even in patients

327 already colonized to prevent progression to VRE infection in the individual

328 patient $[15,45]$ or transmission into the surrounding environment and other

329 hospitalized patients[2,10,40].

330

331 In this retrospective case-control study, we controlled for multiple confounders

332 with our time and unit matched design. We used machine learning algorithms

333 robust to multi-collinearity and overfitting, and applied permutation heuristics to

334 correct for feature importance bias and decrease our false discovery rate. This

335 study reveals an opportunity for future studies to delineate key differences in

336 pathophysiology between VRE acquisition and domination.

338 In summary, VRE acquisition and expansion may be two distinct processes, and

339 efforts to manipulate the microbiome to prevent the spread of VRE may be more

340 beneficial in reducing VRE domination in colonized patients than in preventing

341 VRE acquisition in un-colonized patients. Future studies of the role of the gut

342 microbiota in VRE acquisition may need to move beyond single time point $16 \mathrm{~S}$

343 analyses and address the role of temporal dynamics and stochasticity of gut

344 microbiota in the acquisition and expansion of VRE.

345 ACKNOWLEDGMENTS:

346 The authors would like to thank Aline Penkevich for assistance with acquiring

347 rectal swabs for sequencing.

348 The authors have no conflicts of interest to disclose. 
medRxiv preprint doi: https://doi.org/10.1101/2020.05.26.20114181; this version posted May 28, 2020. The copyright holder for this preprint

(which was not certified by peer review) is the author/funder, who has granted medRxiv a license to display the preprint in perpetuity.

It is made available under a CC-BY-NC-ND 4.0 International license .

349 RC No conflict, CAB No Conflict, KH No Conflict, NF No Conflict, PR No Conflict,

350 RPD No Conflict, RJW No Conflict.

351 FUNDING:

352 This work was supported by the National Institutes of Health [grant numbers R01

353 HL144599 to R.P.D, R01 Al143852 to R.J.W, 5 T32 HL007749-27 to R.C.]

355 1. Bhalla A, Pultz NJ, Ray AJ et al. Antianaerobic Antibiotic Therapy Promotes

356 Overgrowth of Antibiotic-Resistant, Gram-Negative Bacilli and Vancomycin-

357 Resistant Enterococci in the Stool of Colonized Patients. Infect Control Hosp

358 Epidemiol 2003;24:644-9.

359 2. Caballero S, Kim S, Carter RA et al. Cooperating Commensals Restore

360 Colonization Resistance to Vancomycin-Resistant Enterococcus faecium. Cell

361 Host Microbe 2017;21:592-602.e4.

362 3. Kim SG, Becattini S, Moody TU et al. Microbiota-derived lantibiotic restores

363 resistance against vancomycin-resistant Enterococcus. Nature 2019;572:665-9.

364 4. Centers for Disease Control U. Antibiotic Resistance Threats in the United

365 States, 2019.

366 5. Weiner LM, Webb AK, Limbago B et al. Antimicrobial-Resistant Pathogens

367 Associated With Healthcare-Associated Infections: Summary of Data Reported to

368 the National Healthcare Safety Network at the Centers for Disease Control and

369 Prevention, 2011-2014. Infect Control Hosp Epidemiol 2016, DOI:

$370 \quad 10.1017 /$ ice.2016.174.

371 6. Zirakzadeh A, Gastineau DA, Mandrekar JN et al. Vancomycin-resistant 
medRxiv preprint doi: https://doi.org/10.1101/2020.05.26.20114181; this version posted May 28, 2020. The copyright holder for this preprint

(which was not certified by peer review) is the author/funder, who has granted medRxiv a license to display the preprint in perpetuity.

It is made available under a CC-BY-NC-ND 4.0 International license .

372 enterococcal colonization appears associated with increased mortality among

373 allogeneic hematopoietic stem cell transplant recipients. Bone Marrow Transplant

$374 \quad 2008 ; 41: 385-92$.

375 7. Zirakzadeh A, Patel R. Vancomycin-Resistant Enterococci: Colonization,

376 Infection, Detection, and Treatment. Mayo Clin Proc 2006;81:529-36.

377 8. Bonten MJ, Hayden MK, Nathan C et al. Epidemiology of colonisation of

378 patients and environment with vancomycin-resistant enterococci. Lancet

379 (London, England) 1996;348:1615-

380 9. Fishman N, Infectious Diseases Society of America, Pediatric Infectious

381 Diseases Society. Policy Statement on Antimicrobial Stewardship by the Society

382 for Healthcare Epidemiology of America (SHEA), the Infectious Diseases Society

383 of America (IDSA), and the Pediatric Infectious Diseases Society (PIDS). Infect

384 Control Hosp Epidemiol 2012;33:322-7.

385 10. Ubeda C, Bucci V, Caballero S, et al. Intestinal microbiota containing

386 Barnesiella species cures vancomycin-resistant Enterococcus faecium

387 colonization. Infect Immun 2013;81:965-73.

388 11. Van Der Waaij D, Berghuis-de Vries JM, Lekkerkerk-Van Der Wees JEC.

389 Colonization resistance of the digestive tract in conventional and antibiotic-

390 treated mice. J Hyg (Lond) 1971;69:405-11.

391 12. Buffie CG, Pamer EG. Microbiota-Mediated Colonization Resistance against

392 Intestinal Pathogens., 2013:790-801.

393 13. Cash HL, Whitham C V., Behrendt CL et al. Symbiotic bacteria direct

394 expression of an intestinal bactericidal lectin. Science (80- ) 2006;313:1126-30. 
medRxiv preprint doi: https://doi.org/10.1101/2020.05.26.20114181; this version posted May 28, 2020. The copyright holder for this preprint

(which was not certified by peer review) is the author/funder, who has granted medRxiv a license to display the preprint in perpetuity.

It is made available under a CC-BY-NC-ND 4.0 International license .

395 14. Kobayashi KS, Chamaillard M, Ogura Y et al. Nod2-dependent regulation of

396 innate and adaptive immunity in the intestinal tract. Science (80- ) 2005;307:731-

3974.

398 15. Taur Y, Xavier JB, Lipuma L, et al. Intestinal Domination and the Risk of

399 Bacteremia in Patients Undergoing Allogeneic Hematopoietic Stem Cell

400 Transplantation. Clin Infect Dis 2012;55:905-14.

401 16. Chanderraj R, Millar JA, Patel TS et al. VRE acquisition in a tertiary care

402 hospital: testing the roles of antibiotic use, proton pump inhibitor use, and

403 colonization pressure. Open Forum Infect Dis 2019, DOI: 10.1093/ofid/ofz139.

404 17. Kozich JJ, Westcott SL, Baxter NT et al. Development of a dual-index

405 sequencing strategy and curation pipeline for analyzing amplicon sequence data

406 on the Miseq Illumina sequencing platform. Appl Environ Microbiol

$407 \quad 2013 ; 79: 5112-20$.

408 18. Mason KL, Downward JRE, Mason KD et al. Candida albicans and bacterial

409 microbiota interactions in the cecum during recolonization following broad-

410 spectrum antibiotic therapy. Infect Immun 2012;80:3371-80.

411 19. GitHub - SchlossLab/MiSeq_WetLab_SOP.

412 20. Korbie DJ, Mattick JS. Touchdown PCR for increased specificity and

413 sensitivity in PCR amplification. Nat Protoc 2008;3:1452-6.

414 21. Schloss PD, Westcott SL, Ryabin T et al. Introducing mothur: Open-source,

415 platform-independent, community-supported software for describing and

416 comparing microbial communities. Appl Environ Microbiol 2009;75:7537-41.

417 22. Schloss PD. MiSeq SOP:mothur. MiSeq SOP:mothur 2019. 
418 23. Quast C, Pruesse E, Yilmaz P, et al. The SILVA ribosomal RNA gene

419 database project: improved data processing and web-based tools. Nucleic Acids

420 Research 2012. 41: D590-D596.

421 24. Needleman SB, Wunsch CD. A general method applicable to the search for

422 similarities in the amino acid sequence of two proteins. J Mol Biol 1970;48:443-

42353.

424 25. Caporaso JG, Bittinger K, Bushman FD et al. PyNAST: a flexible tool for

425 aligning sequences to a template alignment. Bioinformatics 2010;26:266-7.

426 26. Wang Q, Garrity GM, Tiedje JM et al. Naïve Bayesian classifier for rapid

427 assignment of rRNA sequences into the new bacterial taxonomy. App/ Environ

428 Microbiol 2007;73:5261-7.

429 27. Sogin ML, Morrison HG, Huber JA et al. Microbial diversity in the deep sea

430 and the underexplored "rare biosphere." Proc Natl Acad Sci U S A

$431 \quad 2006 ; 103: 12115-20$.

432 28. Westcott SL, Schloss PD. OptiClust, an Improved Method for Assigning

433 Amplicon-Based Sequence Data to Operational Taxonomic Units. mSphere 2,

434 DOI: 10.1128/mSphereDirect.00073-17.

435 29. Matthews BW. Comparison of the predicted and observed secondary

436 structure of T4 phage lysozyme. BBA - Protein Struct 1975;405:442-51.

437 30. Oksanen J, Blanchet FG, Kindt R et al. Vegan: Community Ecology Package.

$438 \quad$ R package version 2.0-2. 2012.

439 31. R Development Core Team R. R: A Language and Environment for Statistical

440 Computing., 2019. 
medRxiv preprint doi: https://doi.org/10.1101/2020.05.26.20114181; this version posted May 28, 2020. The copyright holder for this preprint

(which was not certified by peer review) is the author/funder, who has granted medRxiv a license to display the preprint in perpetuity.

It is made available under a CC-BY-NC-ND 4.0 International license .

441 32. Wang Y, Naumann U, Wright ST et al. Mvabund- an R package for model-

442 based analysis of multivariate abundance data. Methods Ecol Evol 2012;3:471-

4434.

444 33. ter Braak CJF, Peres-Neto P, Dray S. A critical issue in model-based

445 inference for studying trait-based community assembly and a solution. PeerJ

446 2017;2017, DOI: 10.7717/peerj.2885.

447 34. Wright MN, Ziegler A. Ranger: A fast implementation of random forests for

448 high dimensional data in C++ and R. J Stat Softw 2017;77, DOI:

449 10.18637/jss.v077.i01.

450 35. Kuhn M. Building predictive models in $\mathrm{R}$ using the caret package. $J$ Stat

451 Softw 2008;28:1-26.

452 36. Altmann A, Toloşi L, Sander O et al. Permutation importance: a corrected

453 feature importance measure. Bioinformatics 2010;26:1340-7.

454 37. Therneau T. A Package for Survival Analysis in S. 2015.

455 38. Therneau T, Grambsh P. Modeling Survival Data: Extending the Cox Model.

456 New York: Springer-Verlag, 2000.

457 39. Burnham KP, Anderson DR. Multimodel Inference. Sociol Methods Res

$458 \quad 2004 ; 33: 261-304$.

459 40. Donskey CJ, Chowdhry TK, Hecker MT et al. Effect of Antibiotic Therapy on

460 the Density of Vancomycin-Resistant Enterococci in the Stool of Colonized

$461 \quad$ Patients. N Engl J Med 2000;343:1925-32.

462 41. Ojima M, Motooka D, Shimizu K et al. Metagenomic Analysis Reveals

463 Dynamic Changes of Whole Gut Microbiota in the Acute Phase of Intensive Care 
464 Unit Patients. Dig Dis Sci 2016;61:1628-34.

465 42. Dubin KA, Mathur D, McKenney PT et al. Diversification and Evolution of

466 Vancomycin-Resistant Enterococcus faecium during Intestinal Domination. Infect

467 Immun 2019;87, DOI: 10.1128/IAI.00102-19.

468 43. Pendleton KM, Erb-Downward JR, Bao Y et al. Rapid Pathogen Identification

469 in Bacterial Pneumonia Using Real-Time Metagenomics. Am J Respir Crit Care

$470 \quad$ Med 2017;196:1610-2.

471 44. Chanderraj R, Dickson RP. Rethinking pneumonia: A paradigm shift with

472 practical utility. Proc Natl Acad Sci U S A 2018;115:13148-50.

473 45. Ubeda C, Taur Y, Jenq RR et al. Vancomycin-resistant Enterococcus

474 domination of intestinal microbiota is enabled by antibiotic treatment in mice and

475 precedes bloodstream invasion in humans. J Clin Invest 2010;120:4332-41. 
medRxiv preprint doi: https://doi.org/10.1101/2020.05.26.20114181; this version posted May 28, 2020. The copyright holder for this preprint (which was not certified by peer review) is the author/funder, who has granted medRxiv a license to display the preprint in perpetuity. It is made available under a CC-BY-NC-ND 4.0 International license .

Table 1. Demographics and Comorbidities of Matched Cohorts

\begin{tabular}{lccc}
\hline & $\begin{array}{c}\text { Controls } \\
\mathrm{n}=59\end{array}$ & $\begin{array}{c}\text { Cases } \\
\mathrm{n}=59\end{array}$ & P-value \\
\hline Demographics & & & \\
Age (mean \pm SE) & $57.19 \pm 1.62$ & $60.2 \pm 1.95$ & 0.23 \\
Female & $23(0.39)$ & $22(0.38)$ & 0.56 \\
Non-white race & $9(0.15)$ & $9(0.15)$ & 0.28 \\
Diagnoses and comorbidities & & & \\
C. difficile infection & $4(0.07)$ & $11(0.18)$ & 0.07 \\
Leukemia & $21(0.36)$ & $17(0.29)$ & 0.38 \\
Lymphoma & $12(0.21)$ & $10(0.17)$ & 0.49 \\
Bone marrow transplant & $15(0.25)$ & $14(0.24)$ & 0.64 \\
Solid organ malignancy & $35(0.6)$ & $40(0.67)$ & 0.33 \\
Metastatic malignancy & $29(0.49)$ & $35(0.59)$ & 0.10 \\
Diabetes & $27(0.46)$ & $23(0.39)$ & 0.59 \\
Coronary artery disease & $6(0.11)$ & $10(0.17)$ & 0.72 \\
Congestive heart failure & $19(0.32)$ & $18(0.3)$ & 0.60 \\
COPD & $21(0.35)$ & $36(0.61)$ & 0.02 \\
Peripheral vascular disease & $6(0.1)$ & $2(0.03)$ & 0.31 \\
End stage renal disease & $18(0.31)$ & $26(0.44)$ & 0.07 \\
Connective tissue disease & $1(0.01)$ & $4(0.06)$ & 0.35 \\
Peptic ulcer disease & $9(0.15)$ & $6(0.11)$ & 0.50 \\
Cirrhosis & $2(0.04)$ & $9(0.15)$ & 0.06 \\
Cerebrovascular disease & $12(0.21)$ & $17(0.29)$ & 0.54 \\
Hemiplegia & $4(0.06)$ & $12(0.2)$ & 0.07 \\
Dementia & $1(0.01)$ & $3(0.05)$ & 0.34 \\
Charlson Score (mean $\pm \mathrm{SE})$ & $3.71 \pm 0.22$ & $4.45 \pm 0.25$ & 0.05 \\
\hline
\end{tabular}

Cases and controls were matched by "time at risk" and unit or ward. Values are reported as $\mathrm{n}$ (proportion) unless otherwise noted.

Table 2. Medication Exposure of Matched Cohorts 
medRxiv preprint doi: https://doi.org/10.1101/2020.05.26.20114181; this version posted May 28, 2020. The copyright holder for this preprint (which was not certified by peer review) is the author/funder, who has granted medRxiv a license to display the preprint in perpetuity.

It is made available under a CC-BY-NC-ND 4.0 International license .

\begin{tabular}{|c|c|c|c|c|c|c|}
\hline & $\begin{array}{c}\text { Controls } \\
n=59\end{array}$ & $\begin{array}{l}\text { Cases } \\
\mathrm{n}=59\end{array}$ & $P$ value & $\begin{array}{c}\text { Controls } \\
n=59\end{array}$ & $\begin{array}{l}\text { Cases } \\
\mathrm{N}=59\end{array}$ & $P$ value \\
\hline \multicolumn{7}{|c|}{ Prior to admission swab } \\
\hline \multicolumn{7}{|l|}{ Antibiotics } \\
\hline Any antibiotics & $29(0.49)$ & $40(0.68)$ & 0.05 & $1.72 \pm 0.62$ & $2.32 \pm 0.47$ & 0.44 \\
\hline Vancomycin & $14(0.24)$ & $21(0.36)$ & 0.17 & $0.52 \pm 0.3$ & $0.36 \pm 0.06$ & 0.61 \\
\hline Metronidazole & $8(0.14)$ & $14(0.24)$ & 0.17 & $0.14 \pm 0.04$ & $0.4 \pm 0.16$ & 0.16 \\
\hline Piperacillin-Tazobactam & $8(0.14)$ & $12(0.2)$ & 0.29 & $0.14 \pm 0.04$ & $0.21 \pm 0.06$ & 0.25 \\
\hline Cefepime & $7(0.12)$ & $11(0.19)$ & 0.32 & $0.4 \pm 0.3$ & $0.32 \pm 0.12$ & 0.81 \\
\hline Proton pump inhibitors & $9(0.15)$ & $19(0.32)$ & 0.04 & $0.2 \pm 0.07$ & $0.61 \pm 0.19$ & 0.07 \\
\hline \multicolumn{7}{|c|}{ Between admission and "time at risk" swab } \\
\hline \multicolumn{7}{|l|}{ Antibiotics } \\
\hline Any antibiotics & $56(0.95)$ & $52(0.88)$ & 0.18 & $\begin{array}{c}21.66 \pm \\
4.98\end{array}$ & $\begin{array}{c}22.36 \pm \\
3.66\end{array}$ & 0.82 \\
\hline Vancomycin & $37(0.63)$ & $39(0.66)$ & 0.66 & $3.55 \pm 0.82$ & $3.33 \pm 0.82$ & 0.73 \\
\hline Metronidazole & $20(0.34)$ & $24(0.41)$ & 0.43 & $2.01 \pm 0.72$ & $2.29 \pm 0.6$ & 0.75 \\
\hline Piperacillin-Tazobactam & $26(0.44)$ & $25(0.42)$ & 0.83 & $3.66 \pm 1.13$ & $2.8 \pm 0.64$ & 0.42 \\
\hline Cefepime & $21(0.36)$ & $24(0.41)$ & 0.56 & $2.92 \pm 1.01$ & $3.1 \pm 0.82$ & 0.85 \\
\hline Proton pump inhibitors & $33(0.56)$ & $39(0.66)$ & 0.23 & $5.15 \pm 1.48$ & $6.75 \pm 1.32$ & 0.13 \\
\hline
\end{tabular}

Prevalence values are reported as $\mathrm{n}$ (proportion). Duration values are reported as days of therapy \pm SD. 
medRxiv preprint doi: https://doi.org/10.1101/2020.05.26.20114181; this version posted May 28, 2020. The copyright holder for this preprint (which was not certified by peer review) is the author/funder, who has granted medRxiv a license to display the preprint in perpetuity. It is made available under a CC-BY-NC-ND 4.0 International license .

\section{Figures}

\section{$480 \quad$ Figure 1}

481 A

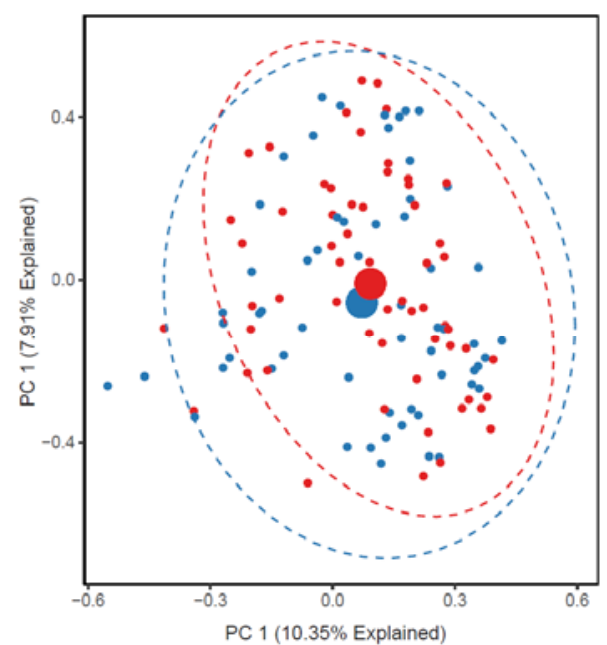

B

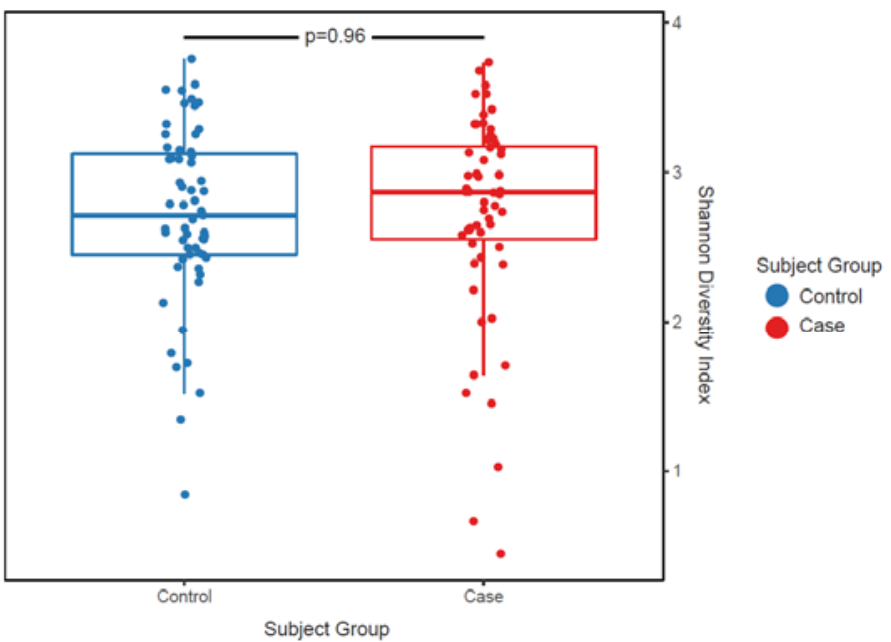


484 Figure 1 In Hospitalized patients, admission gut microbiota do not predict

485 subsequent VRE acquisition. We used 16S rRNA sequencing to characterize

486 gut bacterial communities in 118 hospitalized patients who tested negative for

487 VRE at admission. We compared admission gut microbiota across 59 matched

488 cases (patients who acquired VRE) and controls (patients who did not acquire

489 VRE). A Visualization of admission gut microbial communities using Principal

490 Component Analysis. The admission gut communities of cases and controls did

491 not differ in their community composition, either visually or via permutation

492 testing ( $P=0.3$, PERMANOVA). B. Comparison of average species diversity as

493 measured by Shannon diversity index in admission gut communities. The

494 admission gut communities of cases and controls did not differ in their community

495 Shannon Diversity index ( $p=0.96$, Conditional logistic regression). 
medRxiv preprint doi: https://doi.org/10.1101/2020.05.26.20114181; this version posted May 28, 2020. The copyright holder for this preprint (which was not certified by peer review) is the author/funder, who has granted medRxiv a license to display the preprint in perpetuity.

It is made available under a CC-BY-NC-ND 4.0 International license .
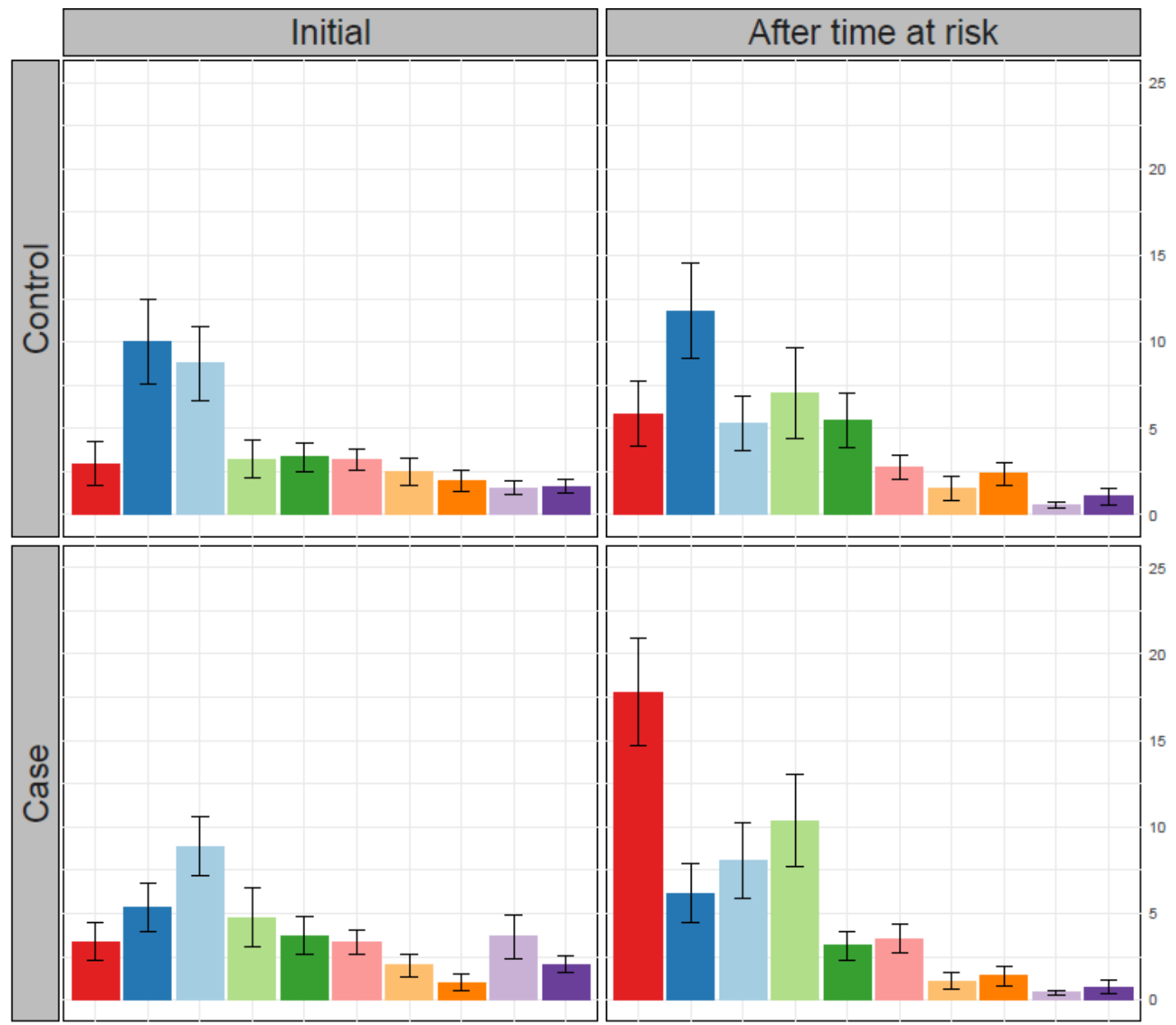

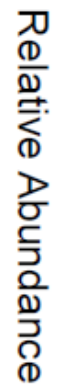

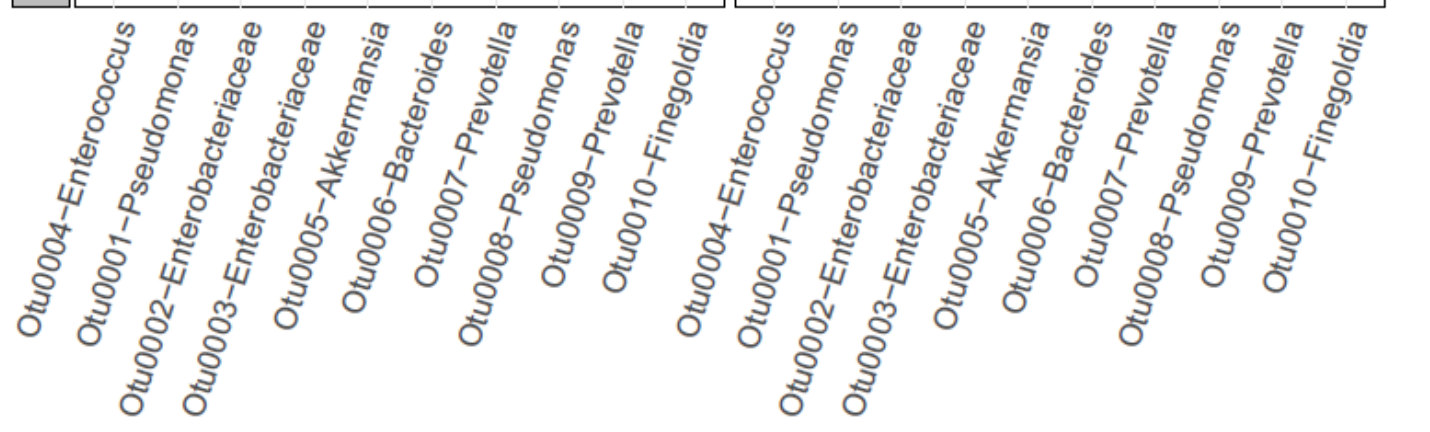


499 Figure 2 After the time at risk, the gut microbiota of cases and controls differ

500 primarily in their relative abundance of Enterococcus. The ten most abundant

501 bacterial taxa are shown in controls (top) and cases (bottom), at the time of

502 admission (left) and following matched time-at-risk (right). Cases and controls did

503 not differ in their admission microbiota (left). After the time-at-risk, the gut

504 microbiota of cases were enriched with Enterococcus relative to control $(\mathrm{P}<0.01$,

505 mvabund), but otherwise did not differ in their community composition ( $p>0.05$

506 for all other taxa, mvabund). 
medRxiv preprint doi: https://doi.org/10.1101/2020.05.26.20114181; this version posted May 28, 2020. The copyright holder for this preprint (which was not certified by peer review) is the author/funder, who has granted medRxiv a license to display the preprint in perpetuity.

It is made available under a CC-BY-NC-ND 4.0 International license.

Figure 3

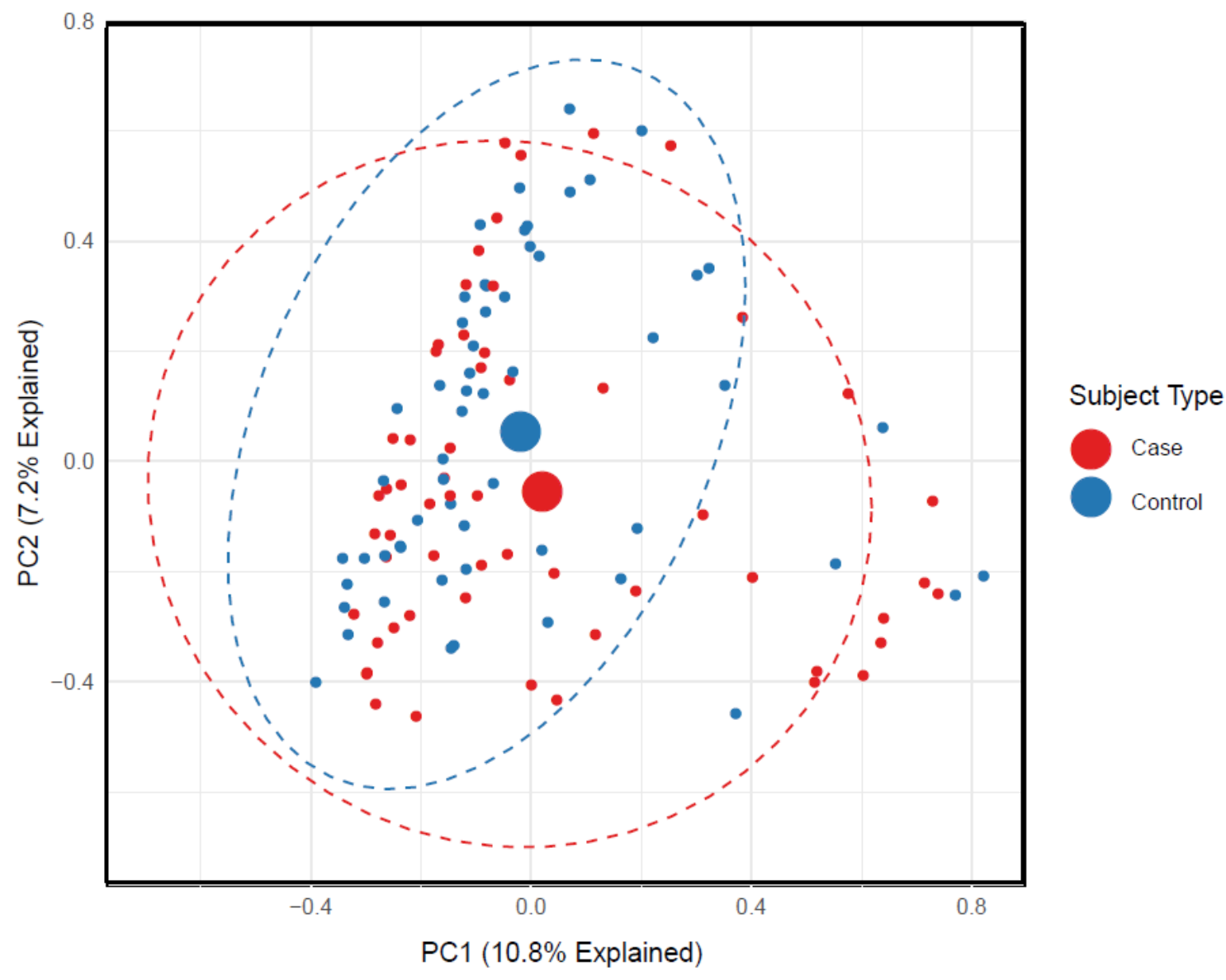

509

510 
medRxiv preprint doi: https://doi.org/10.1101/2020.05.26.20114181; this version posted May 28, 2020. The copyright holder for this preprint (which was not certified by peer review) is the author/funder, who has granted medRxiv a license to display the preprint in perpetuity. It is made available under a CC-BY-NC-ND 4.0 International license.

511 Figure 3 With the exception of Enterococcus, gut communities of VRE infected

512 and uninfected patients do not differ. When we excluded Enterococcus OTU

513 enriched in VRE-infected patients, we found no remaining difference in bacterial

514 community composition, either visually (Principal Component Analysis) or via

515 permutation testing $(\mathrm{P}=0.12 \mathrm{PERMANOVA})$.

516 
medRxiv preprint doi: https://doi.org/10.1101/2020.05.26.20114181; this version posted May 28, 2020. The copyright holder for this preprint (which was not certified by peer review) is the author/funder, who has granted medRxiv a license to display the preprint in perpetuity. It is made available under a CC-BY-NC-ND 4.0 International license.

\section{Figure 4}

518

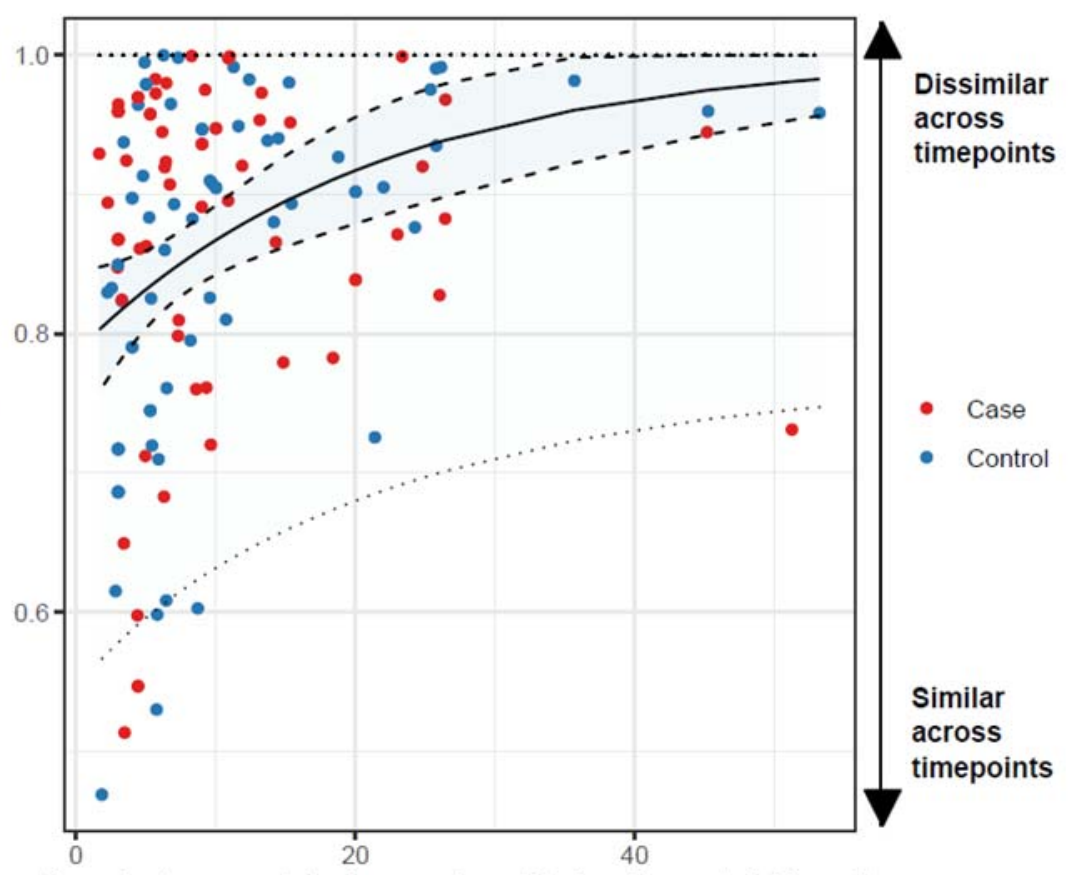

Days between admission swab and index (time at risk) swab 
520 Figure 4 Rapid and dramatic change in gut microbiota among hospitalized

521 patients. We calculated the dissimilarity between admission and subsequent

522 (index, time-at-risk) gut communities in both cohorts with Jaccard distance. Both

523 cases and controls exhibited rapid changes in gut communities during

524 hospitalization, with Jaccard distance changing at an exponential rate. Cases

525 and controls did not differ from each other in temporal disruption of gut

526 microbiota. Dashed lines in the figure represent the 95\% confidence interval for

527 predicted mean Jaccard distance (inner ribbon) and predicted Jaccard distance

528 for an individual subject (outer ribbon). 
medRxiv preprint doi: https://doi.org/10.1101/2020.05.26.20114181; this version posted May 28, 2020. The copyright holder for this preprint (which was not certified by peer review) is the author/funder, who has granted medRxiv a license to display the preprint in perpetuity.

It is made available under a CC-BY-NC-ND 4.0 International license .

530

531

532

533

\section{Figure 5}
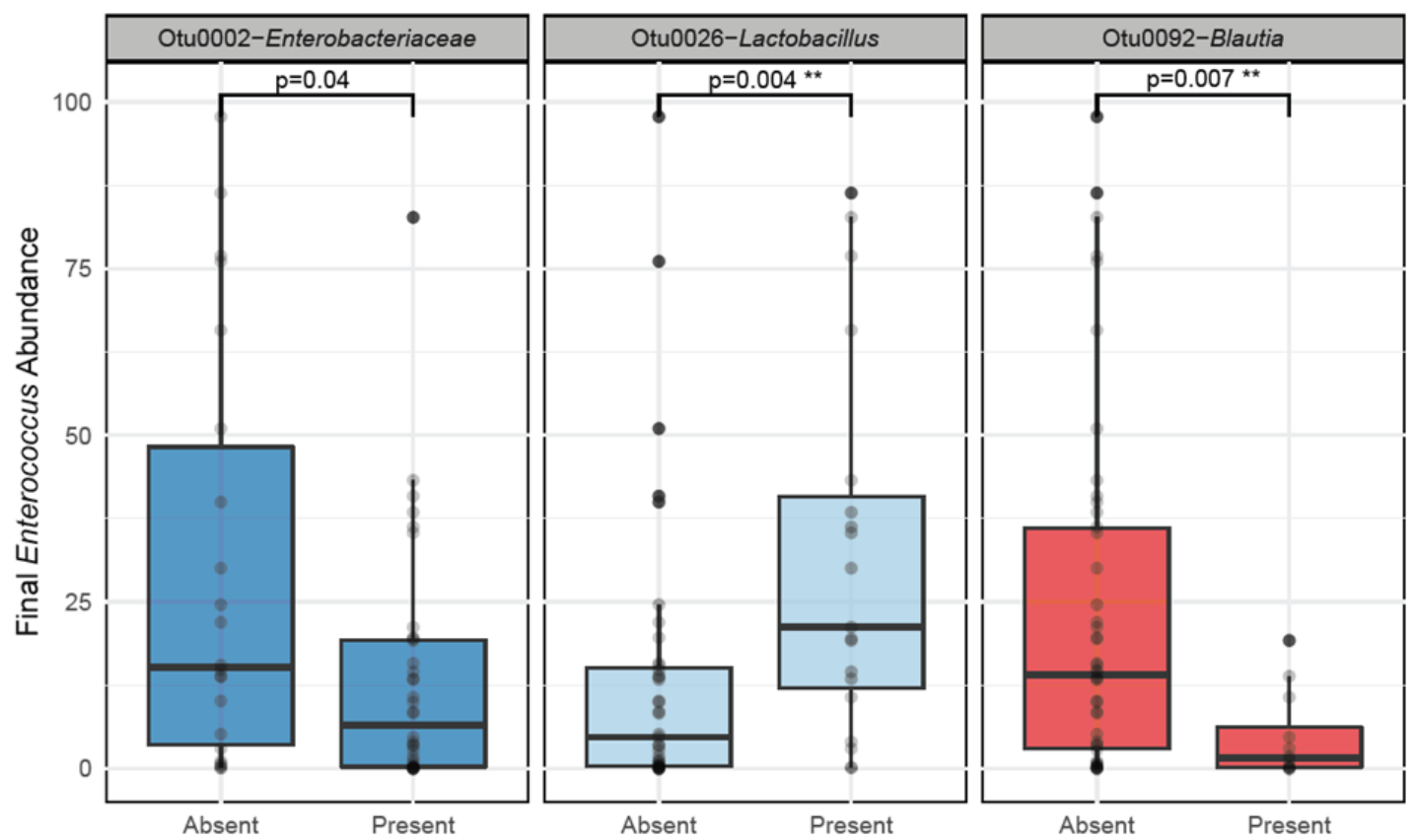
534 Figure 5 Presence of Blautia species on admission is predictive of decreased

535 Enterococcus abundance at the time of VRE acquisition. A random forest

536 regression model identified 7 OTUs present on admission that predicted

537 subsequent relative abundance of Enterococcus spp. Of these, the presence of

538 Enterobacteriaceae spp., Lactobacillus spp., and Blautia spp. were significant

539 predictors of final Enterococcus spp. relative abundance. Only Lactobacillus spp

540 and Blautia spp. remained significant after correcting for multiple testing.

541 Significance determined using the Mann-Whitney $\mathrm{U}$ test controlled for multiple

542 comparisons. 